\title{
Various types of Aquatic Weeds in A Village Fish Pond and Their Control
}

\author{
Abhishek Giri* \\ Prabhat Kumar College, India
}

Submission: August 10, 2020; Published: August 25, 2020

*Corresponding author: Abhishek Giri, Prabhat Kumar College, Kanakpur, Word No-21, Contai, Purba Medinipur, 721401, West Bengal, India

Abstract

Aquatic weeds become menacing to fish cultivation when their growth is excessive. Excessive vegetation of all categories is harmful, be it emergent, floating or submerged type of weed. The disadvantages caused are many. Control of weeds is an important part of pond management. In this topic different types of aquatic weeds with example and their advantages, disadvantages and their control measures are described.

Keywords: Aquatic weeds; Types; Advantages; Disadvantages; Control

\section{Introduction}

Weeds are unwanted aquatic plants of uncontrolled growth. Aquatic plants are the primary producers of the aquatic ecosystem. They help the fishes in providing food, oxygen, shelter etc. The presence of these unwanted and undesirable aquatic plants certainly pose threat to the productive potential of the aquatic body. In fact, the presence of certain aquatic plants is frequently desirable in fish ponds. Any slackness in controlling their excessive growth diminishes productivity of the water body by utilizing the nutrients or check the penetration of sunlight by shading may lead to either super saturation or depletion of $\mathrm{O}_{2}$. Aquatic weeds provide harboring place to predatory and weed fishes are profuse feeders and prolific breeders and over populate themselves. These factors limit the availability of foods. Gases like $\mathrm{H}_{2} \mathrm{~S}$ and $\mathrm{CH}_{4}$ are formed which are harmful to fishes. On the other hand, presence of aquatic weeds in small numbers is necessary because they form natural food for many fishes. They form good fertilizers in the pond when decayed.

Over 140 species of plants have been reported to act as aquatic weeds both within and around various kinds of aquatic bodies in India. The states comprising West Bengal, Odisha, Bihar, Assam, Tripura and Manipur have the maximum incidence of weed infestation ranging from $40-70 \%$, whereas in other states it may range between 20-50\% (Philipose, 1968) [1-5].

\section{Types of Aquatic Weeds}

From fisheries standpoint the most useful classification of weeds based on habitat and habit have been enlisted as follow:

\section{Planktonic algae}

The algae form the phytoplankton. They may be blue green algae, green algae etc. their rapid proliferation results in algal blooms. e.g. Oscillatoria, Microcystis, Anabaena, Volvox etc (Figure 1-4).
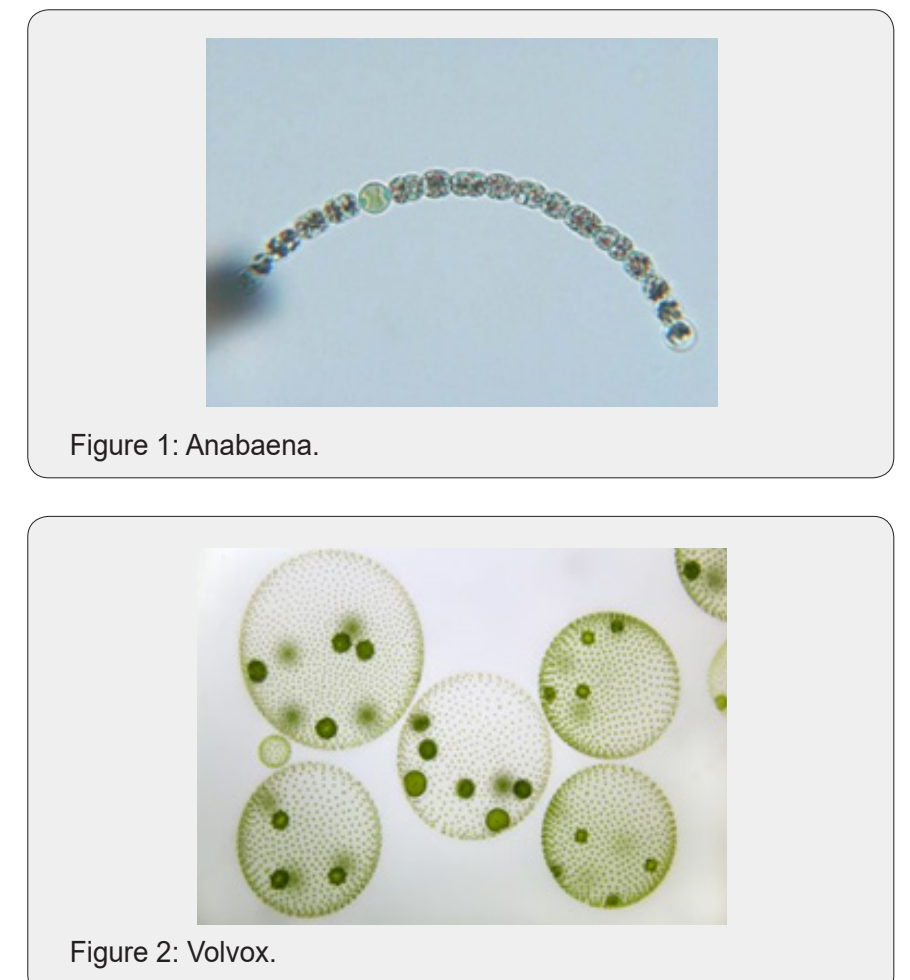


\section{International Journal of Environmental Sciences \& Natural Resources}

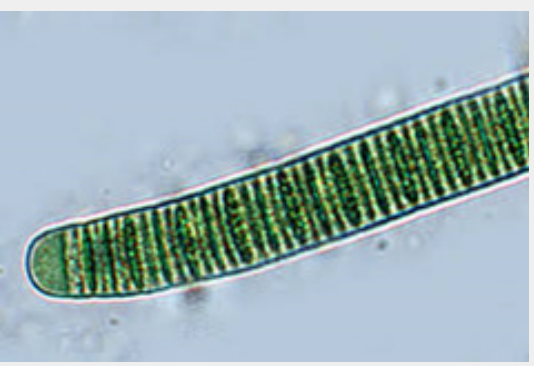

Figure 3: Oscillatoria.

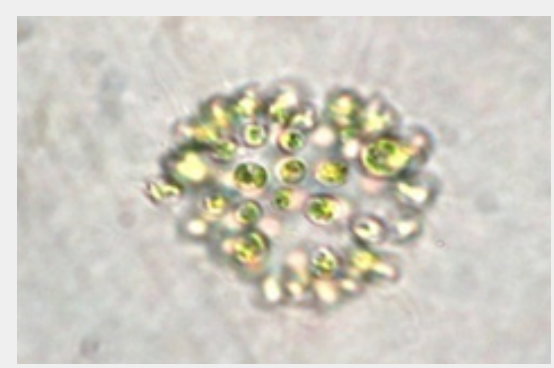

Figure 4: Microcystis.

\section{Filamentous algae}

These algae form 'algal mats' in and around pond water (Figure 5 \& 6).
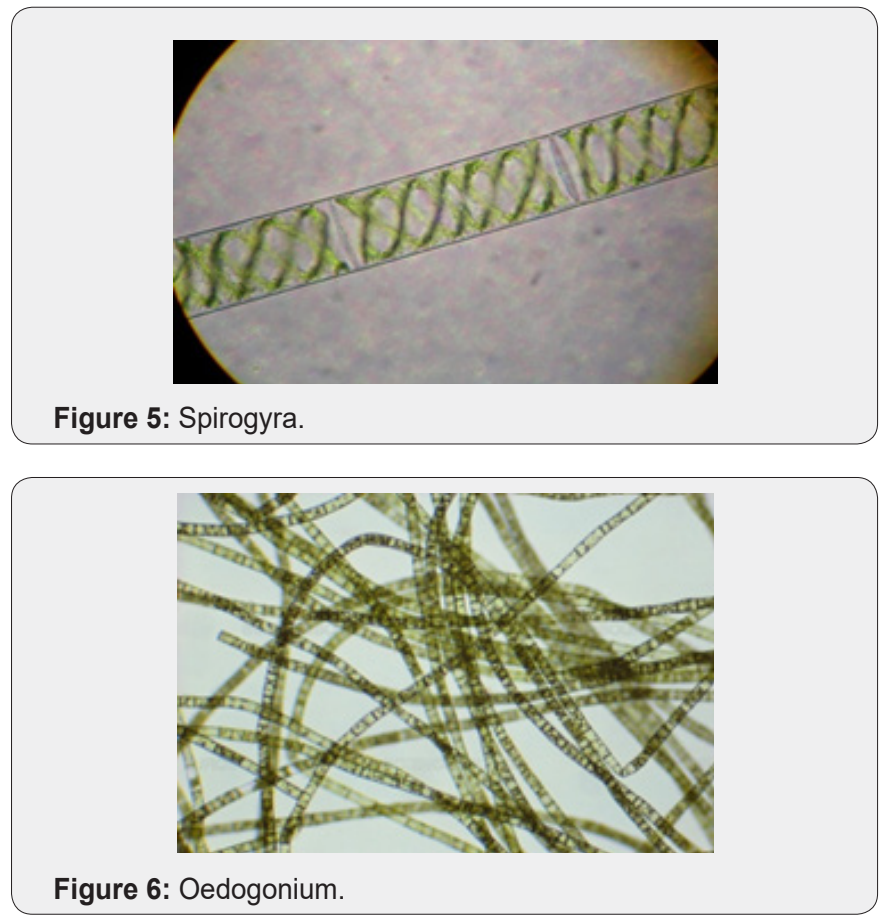

\section{Surface floating weeds}

They are not attached to the pond bottom rather float upon the surface. Sometimes they profusely grow and shade the pond, so are harmful to the fish in many ways. e.g. Azolla, Pistia, Wolfia, Lemna etc (Figure 7-9).
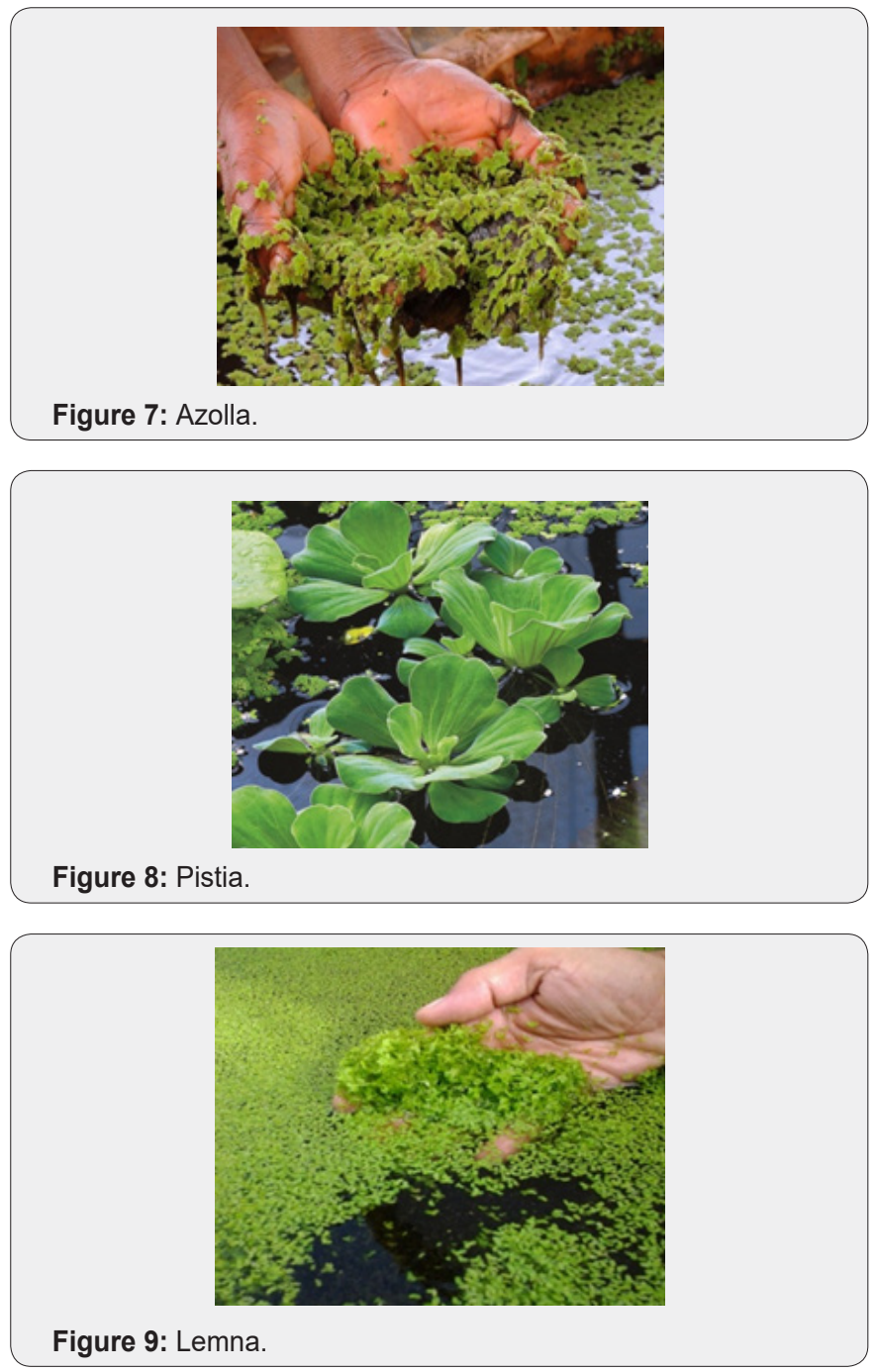

\section{Emergent weeds}

These weeds are rooted in the bottom soil but have all or some of their leaves, leaf, lamina or shoots above the water surface. e.g. Nymphaea, Myriophyllum, Vallisneria etc (Figure 10-12).

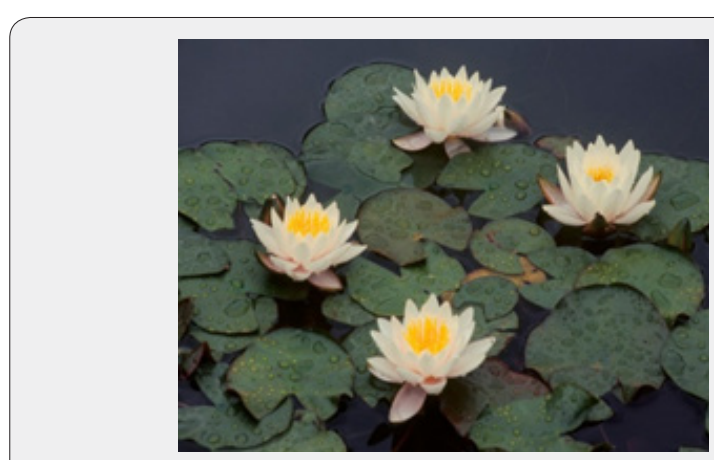

Figure 10: Nymphaea.

\section{Submerged weeds}

These weeds are classified into two groups

i. Completely submerged weeds within the water but may 


\section{International Journal of Environmental Sciences \& Natural Resources}

be rooted in the bottom soil. e.g. Hydrilla, Najas etc (Figure 13 \& 14).

ii. Free floating submerged weed floats freely under the water. e.g. Ceratophyllum, Utricularia etc (Figure 15 \&16).
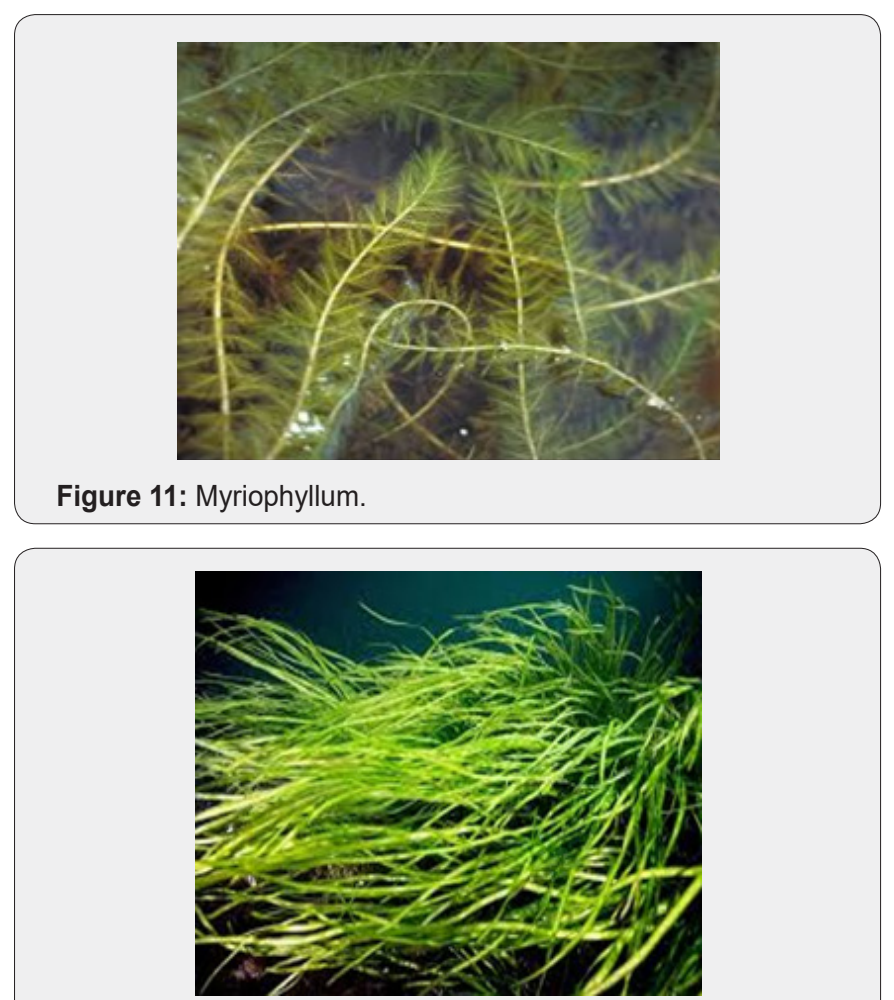

Figure 12: Vallisneria.

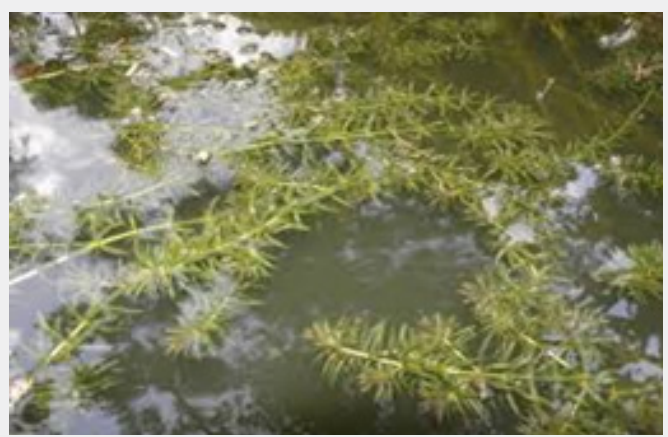

Figure 13: Hydrilla.

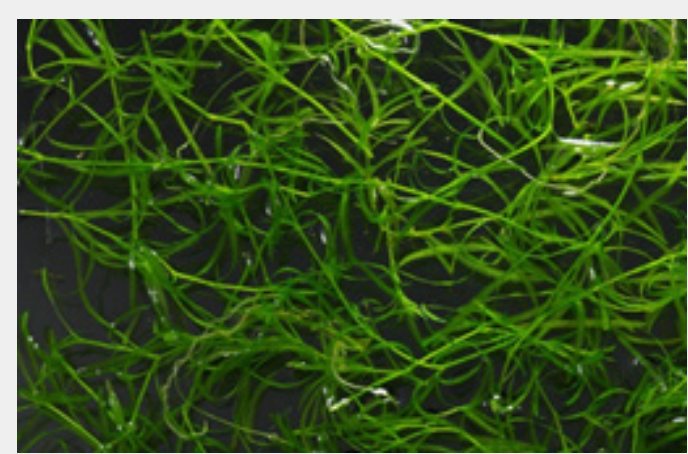

Figure 14: Najas.

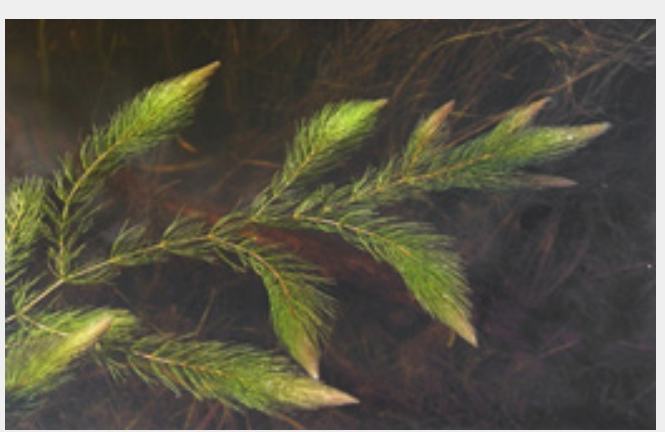

Figure 15: Ceratophyllum.

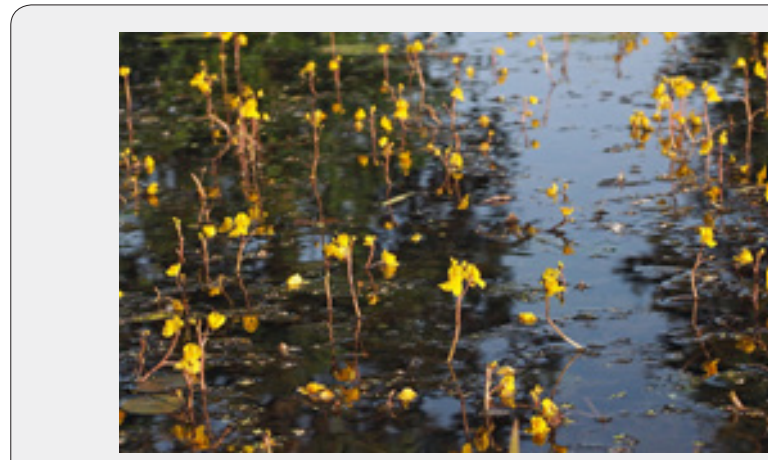

Figure 16: Utricularia.

\section{Marginal weeds}

These types of weeds grow on the margins or on the shore line of the water body. They are mostly rooted in water logged area. e.g. Typha, Nymphaea, Marsilia, Ipomoea etc (Figure 17-19).

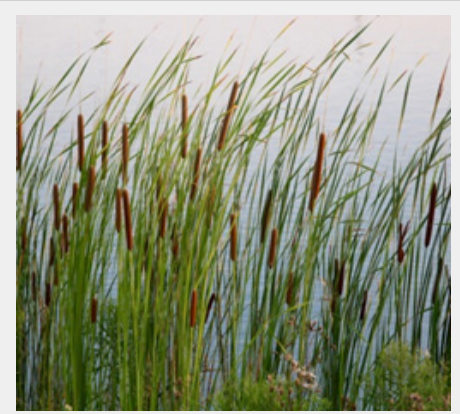

Figure 17: Typha.

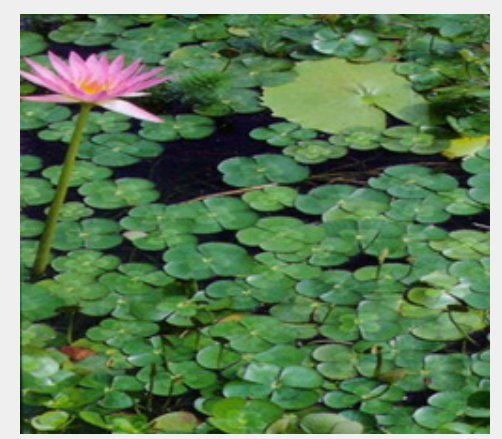

Figure 18: Marsilia. 


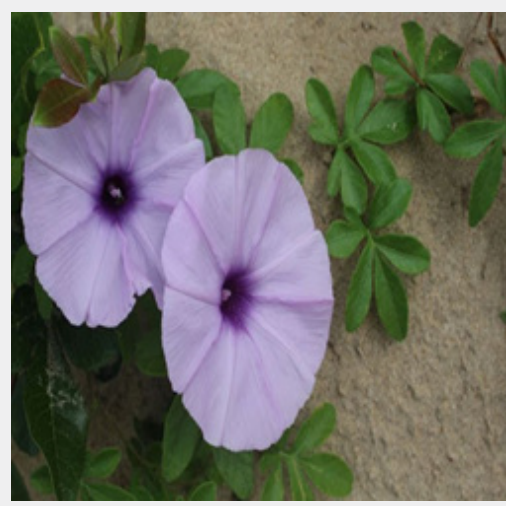

Figure 19: Ipomoea.

\section{Advantages of Aquatic Weeds}
a) They form natural food of many species of fish.
b) Fertilize the pond when decayed.
c) They provide shade and shelter to many fish.
d) Oxygenate the water.
e) They reduce turbidity.
f) Provide spawning beds for fishes.

\section{Disadvantages of Aquatic Weeds}

a) Aquatic weeds occupy more space and they restrict space for fish life.

b) They retard the free movement of fish.

c) Plankton production is reduced.

d) They prevent the penetration of light.

e) They provide shelter for predators and parasites.

f) Aquatic weeds produce Hydrogen Sulphide $\left(\mathrm{H}_{2} \mathrm{~S}\right)$ and Methane $\left(\mathrm{CH}_{4}\right)$ which are harmful to fishes.
g) They consume more nutrients.
h) They obstruct fishing operations.

\section{Control of Aquatic Weeds}

Weeds are controlled by the following methods:

\section{Manual control:}

Weeds can be removed by employing man power with simple devices. They can be removed by hand picking. The floating weeds can be removed by bamboo poles, ropes or nets.

\section{Management control:}

a) Floating weeds can be controlled by constructing barriers. b) Periodic draining and drying of the ponds.

c) Drying and burning.

d) Submerged weeds can be controlled by increasing turbidity.

\section{Mechanical control}

Aquatic weeds can be removed by machines. Water hyacinth can be removed by JCB.

\section{Chemical control}

Weeds can be control by chemicals called weedicides. The weedicides should have the following qualities:

a) They should be cheap and easily available.

b) They should kill the weeds at low concentration.

c) They should be non-toxic to human and fish.

d) They should not pollute the aquatic ecosystem.

\section{Chemical control of floating weeds:}

i. $\quad 2,4-D @ 4.5-6.5 \mathrm{~kg} / \mathrm{hac}$. (Water hyacinth).

ii. Kerosene and Diseale @ 775-1100lit/hac. (Pistia, Lemna).

iii. Paraquat @ 0.02 a/hac. (Pistia, Lemna).

\section{Chemical control of marginal weeds:}

i. 2,4-D @ 5.0kg/hac, 2,2-dichloropropionic sodium @ 10$12 \mathrm{~kg} / \mathrm{hac}$, Amitrol @ 8.0kg/hac. (Typha, Colocasia, Grasses).

ii. Copper sulphate with mud on the bottom soil @ 175kg/ hac. (Nymphae).

\section{Chemical control of emergent weeds:}

i. 2,4-D @ 1.5kg/hac. (Water lilies, Lotus).

\section{Chemical control of submerged weeds:}

i. Sodium arsenite @ 5-6ppm.

ii. Copper sulphate or Copper sulphate with ammonium sulphate@ 50-300ppm.

iii._Ammonia @ 18ppm. (Hydrilla, Najas, Vallisneria).

\section{Biological control}

i. Biological control through herbivorous fishes are Osphronemus gorannmi, Ctenopharyngodon idella (Grass carp), Puntius javonicus (Tawes), Tilapia mossambica, Chanos chanos (Milk fish) have been used.

ii. Some birds have been found in controlling aquatic weeds. For example, Swans, Ducks feed on algae like Wolffia, Lemna, Marginal grasses etc. 


\section{Control through utilization}

Aquatic weeds have economic value. They are used for various purposes. The removal cost of aquatic weeds by manual, mechanical and chemical methods is high and this cost can be compensated by utilizing the weeds for the following purposes

i. Fertilizer

ii. Feed for animals/fishes/birds.

iii. Leaf protein.

iv. Manufacture of paper.

\section{Conclusion}

Native aquatic plants are an important part of the ecosystem, but invasive aquatic weeds degrade the pond habitat and limit the use of affected waters. Most aquatic weeds have been intentionally introduced, so exclusion or prevention is the first line of defense against them. Once a pond has been invaded, several strategies can be used to manage aquatic weeds, including cultural, mechanical, biological and chemical control. Pond owners should first identify the invasive species, then select a product labeled for that weed and for the situation, making sure to apply the product according to label instructions to avoid damage to native plants and fish.

\section{References}

1. Biology and Control of Aquatic Plants: a best management practices handbook. Aquatic Ecosystem Restoration Foundation.

2. Schmidt JC (1987) How to Identify and Control Water weeds and algae. Milwaukee, WI: Applied Biochemists.

3. Anon (1971) Use grass carp for weed control. Indian farming 21(5): $45-47$

4. Singh SB, et al. (1967) Efficiency of grass carp in controlling and utilizing aquatic weeds in India. Proc IPFC 12(2): 220-235.

5. Singh SB (1963) Preliminary experiments on the relative manorial values of some aquatic weeds as compost. Proc IPFC 10(2): 141-145.

\section{Your next submission with Juniper Publishers} will reach you the below assets

- Quality Editorial service

- Swift Peer Review

- Reprints availability

- E-prints Service

- Manuscript Podcast for convenient understanding

- Global attainment for your research

- Manuscript accessibility in different formats ( Pdf, E-pub, Full Text, Audio)

- Unceasing customer service

Track the below URL for one-step submission https://juniperpublishers.com/online-submission.php 